\title{
Delivering alcohol screening and alcohol brief interventions within general dental practice: rationale and overview of the evidence
}

\author{
Andrew McAuley ${ }^{1 *}$, Christine Goodall ${ }^{2}$, Graham Ogden ${ }^{3}$, Simon Shepherd ${ }^{3}$, Karen Cruikshank ${ }^{1}$, Niamh Fitzgerald ${ }^{4}$ \\ From International Network on Brief Interventions for Alcohol Problems (INEBRIA) Meeting 2011 \\ Boston, MA, USA. 21-23 September 2011
}

\begin{abstract}
Alcohol consumption and affordability in the UK has increased over the last 50 years and is associated with a range of adverse oral health outcomes, the most serious of which, oral cancer, is also increasing in incidence. Despite this, routine alcohol screening and brief intervention (SBI) within general dental practice remains uncommon. This review of the literature examined the background and evidence base for undertaking alcohol SBI in general dental practice, including the rationale behind it and the range of issues related to it. Questions addressed include why alcohol consumption is of relevance to dental professionals; what policy context exists for the role of prevention and health promotion in dentistry; what screening tools are appropriate for use within a general dental practice; what evidence of efficacy is there for alcohol SBI in general dental practice; and what barriers and facilitators must be considered before alcohol SBI can be successfully implemented in this setting. We conclude that alcohol SBI in general dental practice, delivered as part of a multidimensional approach to tackling risky alcohol consumption, offer significant potential to improve the oral and general health of the population.
\end{abstract}

\footnotetext{
Author details

${ }^{1}$ Public Health Science Division, NHS Health Scotland, Glasgow, Scotland, UK ${ }^{2}$ Department of Dentistry, Glasgow University, Glasgow, Scotland, UK. ${ }^{3}$ Department of Dental Surgery, University of Dundee Dental Hospital and School, Dundee, Scotland, UK. ${ }^{4}$ Create Consultancy, Ltd., and Robert Gordon University, Aberdeen, Scotland, UK.
}

Published: 9 October 2012

${ }^{1}$ Public Health Science Division, NHS Health Scotland, Glasgow, Scotland, UK Full list of author information is available at the end of the article
doi:10.1186/1940-0640-7-S1-A54

Cite this article as: McAuley et al:: Delivering alcohol screening and alcohol brief interventions within general dental practice: rationale and overview of the evidence. Addiction Science \& Clinical Practice 2012 7(Suppl 1):A54.
Submit your next manuscript to BioMed Central and take full advantage of:

- Convenient online submission

- Thorough peer review

- No space constraints or color figure charges

- Immediate publication on acceptance

- Inclusion in PubMed, CAS, Scopus and Google Scholar

- Research which is freely available for redistribution

Submit your manuscript at www.biomedcentral.com/submit
() Biomed Central
C Biomed Central

(c) 2012 McAuley et al; licensee BioMed Central Ltd. This is an Open Access article distributed under the terms of the Creative Commons Attribution License (http://creativecommons.org/licenses/by/2.0), which permits unrestricted use, distribution, and reproduction in any medium, provided the original work is properly cited. 